\title{
POLYMORPHISMS FOR EXTRA HETEROCHROMATIN IN PHAULACRIDIUM MARGINALE
}

\author{
M. WESTERMAN \\ Deportment of Genetics and Humon Variation, Lo Trobe University, Melbourne, Australia \\ and \\ P. G. FONTANA
}

Deportment of Entomology, McDonald Campus, McGill University, Quebec, Conada

Received 12.x.72

\begin{abstract}
SUMmary
Nine populations of the grasshopper Phaulacridium marginale were investigated cytologically.

One population (OM) was found to be extensively polymorphic for both $B$ chromosomes and supernumerary heterochromatic segments on the three smallest autosomes $\left(\mathrm{S}_{0-11}\right)$.

Differences between populations were demonstrated for mean cell chiasma frequency but not for between-cell variance.

Owing to the small number of individuals sampled and the large number of karyotypic classes possible in OM no meaningful conclusions could be drawn for the effect of the extra heterochromatic on chiasma formation.
\end{abstract}

\section{INTRODUGTION}

THE existence of cytological polymorphisms for extra heterochromatin, present either as supernumerary chromosomes or as extra segments on otherwise normal autosomes, has been demonstrated in many species of plants and animals (White, 1954; Nur, 1961; Lima-de-Faria, 1963; Battaglia, 1964; John and Hewitt, 1965a, b, 1966, 1969). Detailed studies have shown that this extra heterochromatin may be maintained in a species over considerable periods of time (Müntzing, 1954; Lima-de-Faria, 1963; Westerman, 1969; John and Hewitt, 1970), the selective advantage of such polymorphisms being most probably through their positive and causative role in the regulation of recombination. The actual mechanism by which such an effect is mediated is at present unknown.

To date studies on polymorphisms for supernumerary heterochromatin have been confined to species containing either B's or segments since few species have been described as containing both and then only at low frequencies (Hewitt and Schroeter, 1968; Nur, 1969; Hewitt and John, 1971; Shaw, 1971). A meaningful comparison of the modes of action and their possible synergism can however be made only by using an organism in which both types of polymorphism occur at relatively high frequencies. Cytological examination of some specimens of Phaulacridium marginale collected by $\mathrm{Dr} \mathrm{A}$. Mesa and donated to one of the authors (P. G. F.) suggested that both B's and segments coexisted in the same individual. A preliminary population survey was therefore carried out to ascertain how widespread the phenomenon was. 


\section{Materials and methods}

Phaulacridium marginale is a brachypterous grasshopper common throughout New Zealand in open grasslands below $1000 \mathrm{~m}$. (Bigelow, 1967). The species has no close relatives in New Zealand, its closest relative being $P h$. vittatum of Australia from which it is thought to be reproductively isolated (Bigelow loc. cit., p. 109).

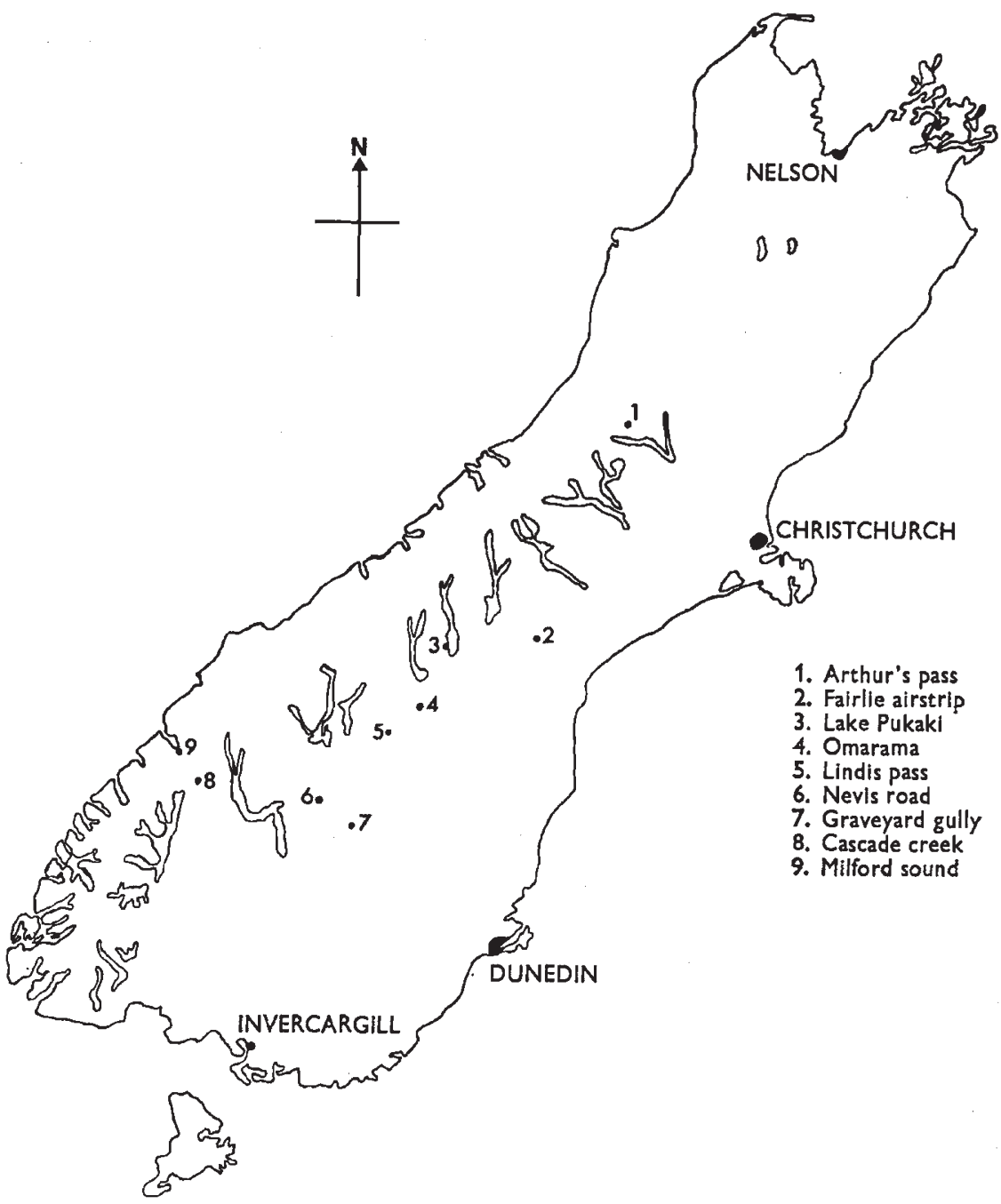

Fic. 1.-The locations of the nine populations of Ph. marginale collected.

During the 1972 meiotic season, samples were taken from nine populations from the southern half of South Island (fig. 1), 20 young adult males being taken wherever possible. Testes were dissected out in insect saline and fixed in 1:3 acetic alcohol, each body and testis being numbered and kept for later reference. Squash preparations in lactopropionic orcein were made from each testis and the karyotype and chiasma frequency recorded. 


\section{ResUlts AND DISCUSSION}

a. The karyotype

In addition to a single allocyclic $\mathrm{X}$ chromosome the standard male complement of Phaulacridium marginale, like that of the closely related $P h$. vittatum, consists of 22 autosomes. This karyotype $(72 n=23$, o $2 n=24)$ is typical of the "Cryptosacci" group of the Acridoidea. The 11 pairs of autosomes are all telecentric and can be divided into three groups on the basis of length $\mathrm{L}_{1-3}, \mathrm{M}_{4-8}$ and $\mathrm{S}_{9-11}$ (see fig. 2). During meiotic prophase the centromeric end of each bivalent is marked by a distinct heterochromatic region.

TABLE 1

Mean cell chiasma frequencies of the karotypic classes present in the Omarama population

\begin{tabular}{|c|c|c|c|c|c|c|}
\hline \multicolumn{2}{|c|}{ Bivalent } & \multicolumn{4}{|c|}{ Number of B chromosomes } & \multirow[b]{2}{*}{ Totals } \\
\hline$S_{9}$ & $S_{10}$ & 0 & 1 & 2 & 3 & \\
\hline $\mathrm{BB}_{\theta}$ & $\left\{\begin{array}{l}\mathrm{BB}_{10} \\
\mathrm{BS}_{10} \\
\mathrm{SS}_{10}\end{array}\right.$ & $\begin{array}{l}15 \cdot 30,15 \cdot 70 \\
17 \cdot 80,16 \cdot 00 \\
20 \cdot 65,18 \cdot 15\end{array}$ & $16.50 \dagger$ & $\begin{array}{l}17.75^{*} \\
15.50\end{array}$ & $\begin{array}{l}17 \cdot 33 \\
15 \cdot 15\end{array}$ & \\
\hline & & 6 & 1 & 2 & 2 & 11 \\
\hline $\mathrm{BS}_{\boldsymbol{\theta}}$ & $\left\{\begin{array}{l}\mathrm{BB}_{10} \\
\mathrm{BS}_{10}\end{array}\right.$ & $\begin{array}{l}16 \cdot 20 \\
17 \cdot 75\end{array}$ & $16 \cdot 60,17 \cdot 55$ & $18 \cdot 45$ & & \\
\hline & & 2 & 2 & 1 & & 5 \\
\hline $\mathrm{SS}_{\theta}$ & $\left\{\begin{array}{l}\mathrm{BB}_{10} \\
\mathrm{BS}_{10} \\
\mathrm{SS}_{10}\end{array}\right.$ & $16 \cdot 45$ & 3 & 3 & 2 & $\begin{array}{r}1 \\
17\end{array}$ \\
\hline & & $\begin{array}{l}* B \\
\dagger B\end{array}$ & (four cells & & & \\
\hline
\end{tabular}

In one of the populations (OM), extensive polymorphism for supernumerary heterochromatin was observed. Eight of the 17 individuals sampled (47 per cent.) were found to carry one or more B chromosomes (see table 1). These $\mathrm{B}$ chromosomes were all of the same morphological type having a nearmedian centromere and being about half the size of the $\mathrm{X}$ chromosome. The two arms of the B chromosome were capable of pairing with one another and crossing over even when the chromosomes were present as univalents and did so frequently. Formation of ring univalents (see fig. 3a) implies at least partial genetic equivalence of the two arms which are probably iso-chromosome derivatives produced by misdivision. When two or more B's were present, these could pair together to form bivalents (see fig. $3 b, c$ ) but they by no means always did so (fig. $3 d$ ). During anaphase I the univalent $\mathrm{B}$ chromosomes move undivided to one pole or other, the direction of movement being random with respect to the univalent $\mathrm{X}$ chromosome or to other univalent B's (fig. $3 e, f)$. The supernumerary chromosomes in this population of Phaulacridium marginale thus appear similar to those already described in $M$. maculatus by John and Hewitt (loc. cit.).

It is of interest to note that the morphology of the B chromosomes from 
the Omarama population of South Island is different from that described from samples of the same species taken from North Island (Martin 1970a, b). In the Wellington population the $B$ is described as being telocentric with a small proximal heterochromatic region separated by a region of euchromatin from a larger more distal block of heterochromatin. No B ring univalents were described by Martin. Sampling from a larger number of populations should ascertain whether the two types of $B$ chromosome are really different or merely derived one from the other by inversion. Jackson and Cheung (1967) have reported B chromosomes in Phaulacridium vittatum which are also telocentric in nature.

Coincident with this polymorphism for B chromosomes the Omarama population was also found to contain supernumerary heterochromatic segments on the three smallest chromosomes $S_{9-11}$. As with those described already in Chorthippus parallelus (John and Hewitt, 1966, 1969; Westerman, 1969, 1970), these extra segments were terminal (see figs. $3 c$ and $4 a-c)$, and represent an addition of from 30 to 50 per cent. more material to that normally present in these chromosomes. The segments were positively heteropycnotic from zygotene to diakinesis and at anaphase I invariably divided equationally. The distribution of the karyotypic classes is shown in table 1. Whilst no firm conclusions can be drawn owing to the small sample size, it would appear that the observed frequencies of the $S_{\theta}$ and $S_{10}$ karyotypes are in agreement with those expected on a Hardy-Weinberg distribution $\left(q_{9}=0.7941 ; q_{10}=0.6176\right)$.

Two individuals were found also to be heterozygous for extra heterochromatic segments on the smallest autosome, $\mathrm{S}_{11}$. The metaphase orientation was such that this unequal bivalent invariably moved reductionally at first anaphase and equationally at second (see fig. $4 d$ ). This behaviour suggests that the segment may be proximal or interstitial in location and that a single chiasma is formed in the short distal segment. A similar unequal $S_{11}$ bivalent has been described from another population of $P h$. marginale (Martin loc. cit.).

In spite of the heterochromatic nature of both the B chromosomes and the extra segments and the known propensity for such material to associate, these extra elements were in no case seen to associate either specifically or non-specifically. It would appear therefore that the origin of the extra segments from translocated pieces of B chromosome material is unlikely (see also Shaw, 197I).

\section{b. Chiasma frequencies}

The chiasma frequency data for the nine populations are summarised in table 2. An analysis of variance on the mean cell chiasma frequencies showed that the populations differ significantly from one another for this metric (table $3 a$ ). No significant difference between populations was observed for between-cell variance (table $3 b$ ). Plotting population means against various environmental parameters such as rainfall however revealed no significant correlations. Three of the population means (OM, GG and NR) appear to be higher than the others. The nine population means were therefore compared using Duncan's new multiple range test (see Steel and Torrey, 1960, p. 107). This test confirms that the OM and GG populations are significantly different from all others, but not from each other; whilst the 


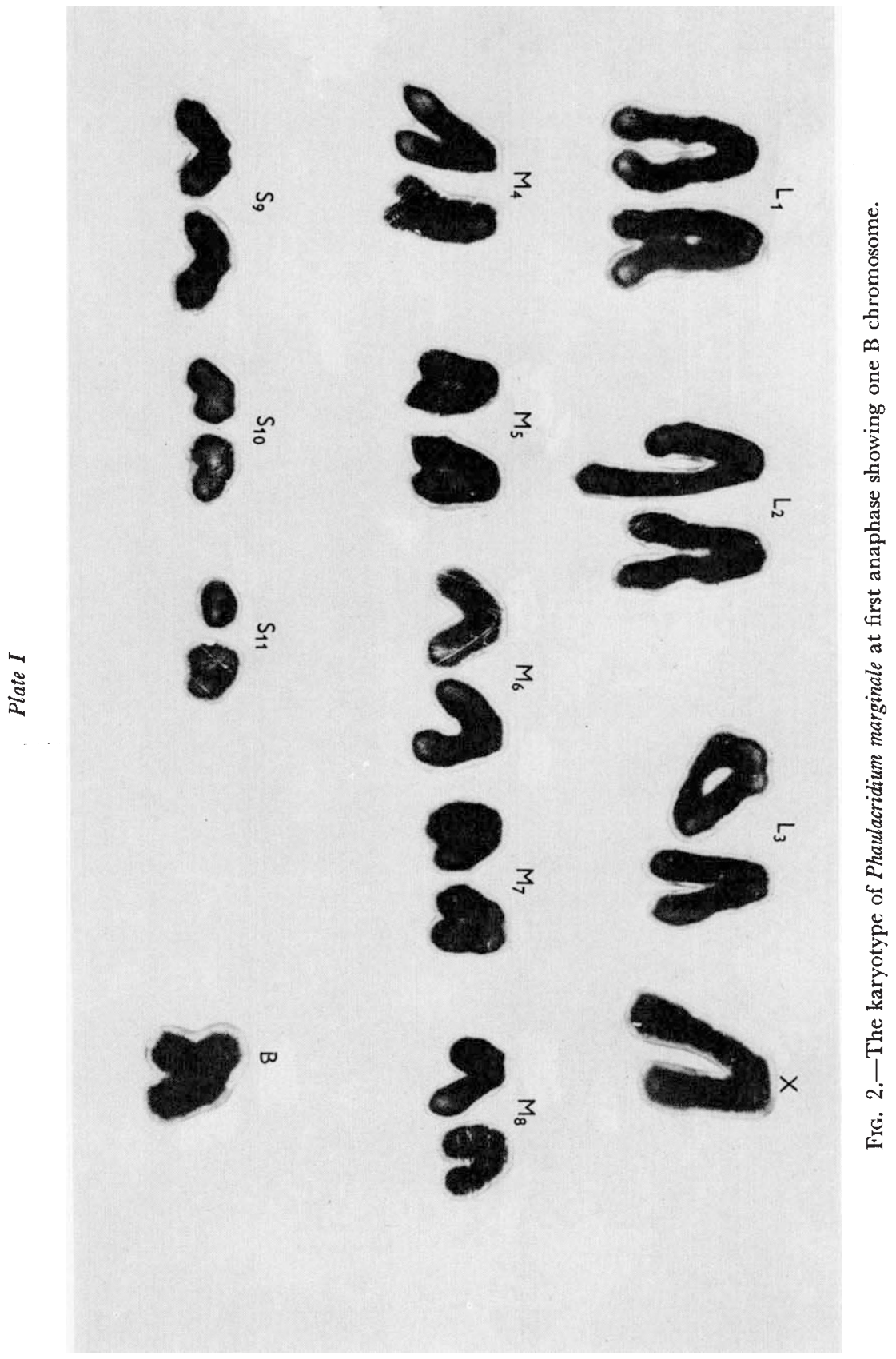



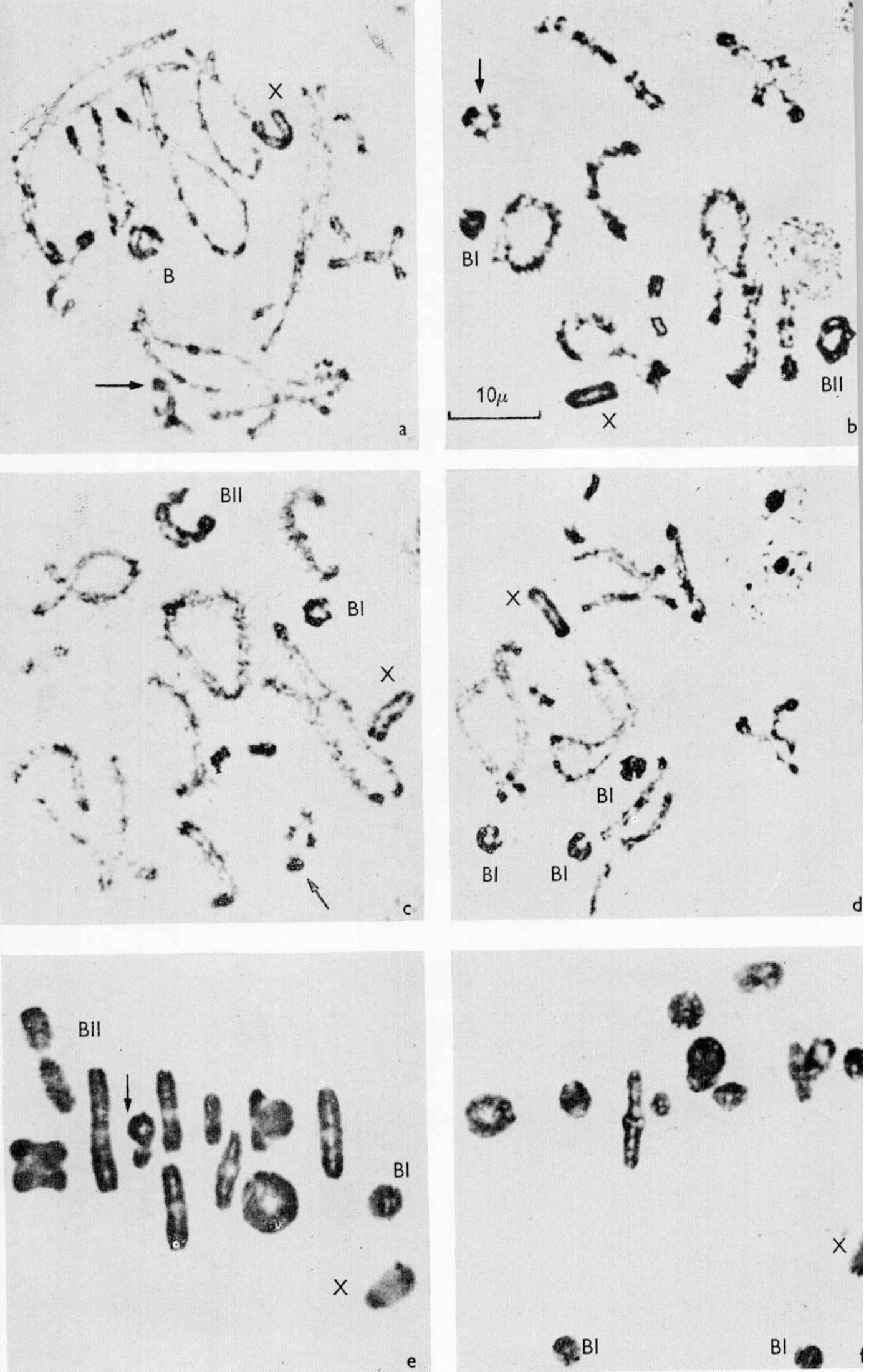

Fig. 3.-Behaviour of $\mathrm{B}$ chromosomes at diplotene and metaphase I. B's present as $(a) \mathrm{B}$ ring univalent, $(b)$ ring bivalent + ring univalent, $(c)$ one chain bivalent + ring univalent, $(d)$ three $\mathrm{B}$ ring univalents, $(e, f)$ two ring univalents. Arrow indicates supernumerary segment. 


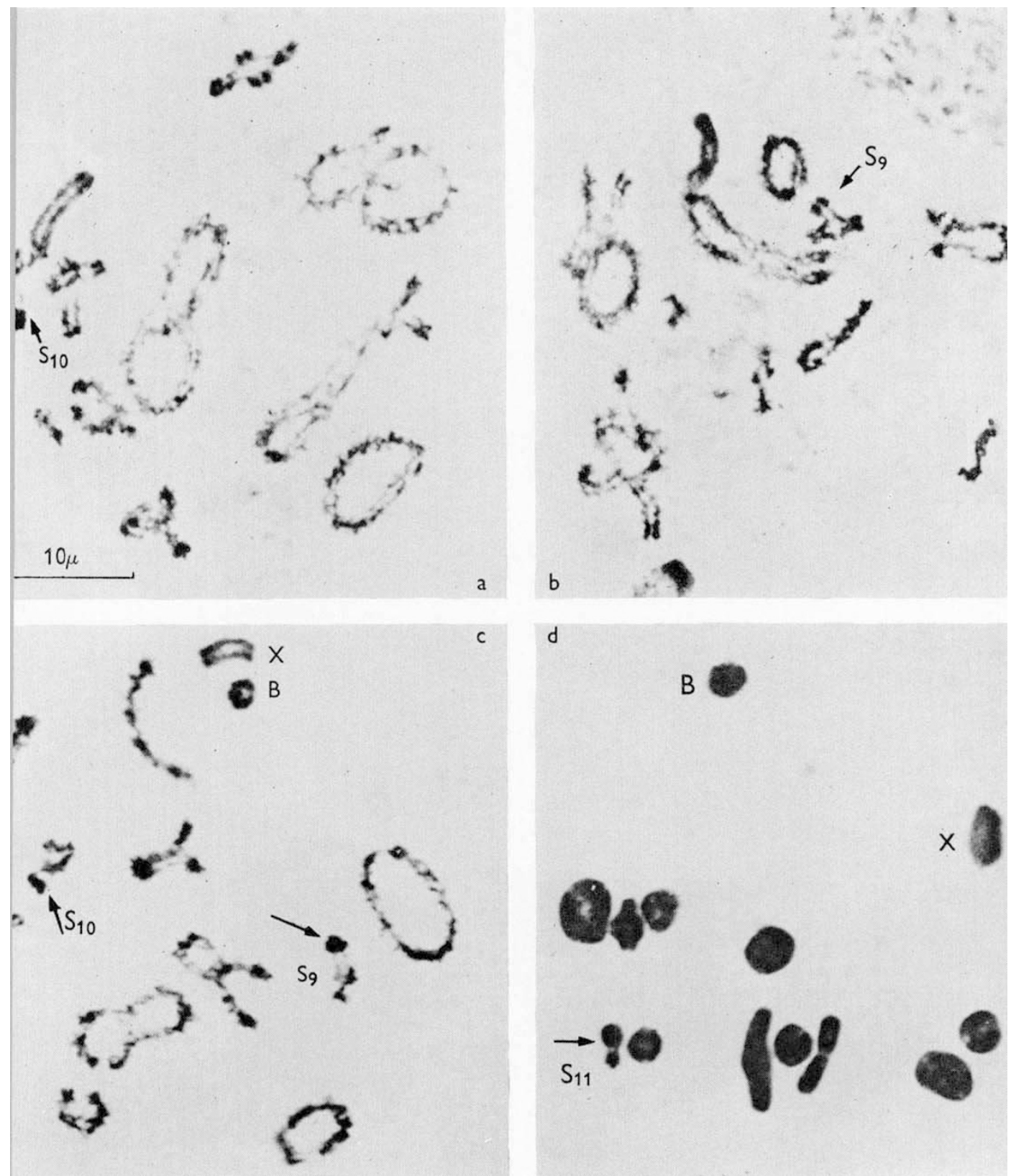

FIG. 4.-Supernumerary heterochromatic segments in Phaulacridium marginale. (a) Diakinesis cell showing $\mathrm{BS}_{10},(b)$ diakinesis cell showing $\mathrm{BS}_{9},(c)$ diakinesis cell showing BS $\mathrm{S}_{0}$ and BS $\mathrm{S}_{10},(d)$ metaphase I cell with BS $\mathrm{S}_{11}$. 
TABLE 2

Mean cell chiasma frequency $(\bar{x} a)$ and between-cell variance $(v x)$ for each individual sampled

Population

\begin{tabular}{|c|c|c|c|c|c|c|c|c|c|}
\hline Individual & OM & NR & GG & FA & GC & MS & AP & LAP & LP \\
\hline 1 & $\begin{array}{r}17 \cdot 33 \\
0.75\end{array}$ & $\begin{array}{r}17.80 \\
1.96\end{array}$ & $\begin{array}{r}18 \cdot 80 \\
1.07\end{array}$ & $\begin{array}{r}15 \cdot 10 \\
0.99\end{array}$ & $\begin{array}{r}15.30 \\
0.90\end{array}$ & $\begin{array}{r}15 \cdot 40 \\
1.38\end{array}$ & $\begin{array}{r}15 \cdot 00 \\
1.33\end{array}$ & $\begin{array}{r}15 \cdot 10 \\
1.43\end{array}$ & $\begin{array}{r}14 \cdot 00 \\
2 \cdot 67\end{array}$ \\
\hline 2 & $\begin{array}{r}20.65 \\
1.29\end{array}$ & $\begin{array}{r}17 \cdot 90 \\
2 \cdot 10\end{array}$ & $\begin{array}{r}15.80 \\
0.40\end{array}$ & $\begin{array}{r}14.00 \\
0.22\end{array}$ & $\begin{array}{r}15.00 \\
0.44\end{array}$ & $\begin{array}{r}15.60 \\
0.71\end{array}$ & $\begin{array}{r}13.70 \\
1.12\end{array}$ & $\begin{array}{r}16.00 \\
1.33\end{array}$ & $\begin{array}{r}15.70 \\
1.79\end{array}$ \\
\hline 3 & $\begin{array}{r}16.50 \\
1.74\end{array}$ & $\begin{array}{r}14 \cdot 80 \\
0 \cdot 62\end{array}$ & $\begin{array}{r}18.80 \\
0.40\end{array}$ & $\begin{array}{r}15.40 \\
2.04\end{array}$ & $\begin{array}{r}14.60 \\
1.38\end{array}$ & $\begin{array}{r}15.30 \\
0.68\end{array}$ & $\begin{array}{r}13.80 \\
0.40\end{array}$ & $\begin{array}{r}16.70 \\
0.90\end{array}$ & $\begin{array}{r}14.70 \\
1 \cdot 12\end{array}$ \\
\hline 4 & $\begin{array}{r}16.60 \\
0.49\end{array}$ & $\begin{array}{r}16.80 \\
1.51\end{array}$ & $\begin{array}{r}16.50 \\
1.39\end{array}$ & $\begin{array}{r}14 \cdot 20 \\
0.40\end{array}$ & $\begin{array}{r}14.80 \\
1.73\end{array}$ & $\begin{array}{r}16.10 \\
1.43\end{array}$ & $\begin{array}{r}15 \cdot 10 \\
2 \cdot 54\end{array}$ & $\begin{array}{r}14.80 \\
1.07\end{array}$ & $\begin{array}{r}14 \cdot 10 \\
0.99\end{array}$ \\
\hline 5 & $\begin{array}{r}15 \cdot 30 \\
1.38\end{array}$ & $\begin{array}{r}18.50 \\
1.83\end{array}$ & $\begin{array}{r}16.40 \\
0.49\end{array}$ & $\begin{array}{r}13.30 \\
1.12\end{array}$ & $\begin{array}{r}16 \cdot 00 \\
0.89\end{array}$ & $\begin{array}{r}15 \cdot 40 \\
1 \cdot 16\end{array}$ & $\begin{array}{r}15 \cdot 30 \\
0.90\end{array}$ & $\begin{array}{r}14.90 \\
0.32\end{array}$ & $\begin{array}{r}15 \cdot 60 \\
2.93\end{array}$ \\
\hline 6 & $\begin{array}{r}17.80 \\
2.69\end{array}$ & $\begin{array}{r}14.60 \\
0.27\end{array}$ & $\begin{array}{r}16.30 \\
2.90\end{array}$ & $\begin{array}{r}14.30 \\
1.57\end{array}$ & $\begin{array}{r}16.30 \\
1.79\end{array}$ & $\begin{array}{r}16.40 \\
2.93\end{array}$ & $\begin{array}{r}14.30 \\
0.90\end{array}$ & $\begin{array}{r}13.50 \\
0.72\end{array}$ & $\begin{array}{r}15 \cdot 00 \\
0.22\end{array}$ \\
\hline 7 & $\begin{array}{r}15 \cdot 15 \\
1 \cdot 29\end{array}$ & $\begin{array}{r}15 \cdot 10 \\
1 \cdot 43\end{array}$ & $\begin{array}{r}16.50 \\
0.72\end{array}$ & $\begin{array}{r}13.90 \\
0.99\end{array}$ & $\begin{array}{r}15.40 \\
1.82\end{array}$ & $\begin{array}{r}14.60 \\
2.04\end{array}$ & $\begin{array}{r}15 \cdot 50 \\
0.50\end{array}$ & $\begin{array}{r}14.50 \\
0.94\end{array}$ & $\begin{array}{r}16.30 \\
0.68\end{array}$ \\
\hline 8 & $\begin{array}{r}17.75 \\
2.62\end{array}$ & $\begin{array}{r}15 \cdot 70 \\
2 \cdot 23\end{array}$ & $\begin{array}{r}16.40 \\
0.71\end{array}$ & $\begin{array}{r}14 \cdot 10 \\
0.77\end{array}$ & $\begin{array}{r}15 \cdot 70 \\
2 \cdot 46\end{array}$ & $\begin{array}{r}15 \cdot 30 \\
0.90\end{array}$ & $\begin{array}{r}13.80 \\
2.18\end{array}$ & $\begin{array}{r}14 \cdot 10 \\
0.32\end{array}$ & $\begin{array}{r}15 \cdot 20 \\
1.07\end{array}$ \\
\hline 9 & $\begin{array}{r}18.45 \\
2.68\end{array}$ & $\begin{array}{r}14.90 \\
1.21\end{array}$ & $\begin{array}{r}14.80 \\
1.07\end{array}$ & $\begin{array}{r}16.40 \\
0.93\end{array}$ & $\begin{array}{r}15 \cdot 10 \\
0.99\end{array}$ & $\begin{array}{r}16.30 \\
1.57\end{array}$ & $\begin{array}{r}15 \cdot 70 \\
2 \cdot 01\end{array}$ & $\begin{array}{r}16.10 \\
0.99\end{array}$ & $\begin{array}{r}14.00 \\
0.67\end{array}$ \\
\hline 10 & $\begin{array}{r}16.45 \\
2.05\end{array}$ & $\begin{array}{r}15 \cdot 60 \\
1 \cdot 16\end{array}$ & $\begin{array}{r}17 \cdot 50 \\
2 \cdot 72\end{array}$ & $\begin{array}{r}14.80 \\
1.73\end{array}$ & $\begin{array}{r}16.20 \\
1.51\end{array}$ & $\begin{array}{r}15 \cdot 00 \\
2 \cdot 22\end{array}$ & $\begin{array}{r}14.60 \\
0.71\end{array}$ & $\begin{array}{r}14.40 \\
0.93\end{array}$ & $\begin{array}{r}14.50 \\
0.72\end{array}$ \\
\hline 11 & $\begin{array}{r}17.55 \\
2.26\end{array}$ & $\begin{array}{r}15 \cdot 30 \\
0.90\end{array}$ & $\begin{array}{r}15 \cdot 30 \\
0.90\end{array}$ & $\begin{array}{r}14 \cdot 20 \\
0.62\end{array}$ & $\begin{array}{r}15 \cdot 20 \\
0.62\end{array}$ & $\begin{array}{r}14.80 \\
1.07\end{array}$ & $\begin{array}{r}15.70 \\
1.57\end{array}$ & $\begin{array}{r}15 \cdot 10 \\
0.32\end{array}$ & $\begin{array}{r}14.20 \\
1.96\end{array}$ \\
\hline 12 & $\begin{array}{r}16 \cdot 00 \\
0.89\end{array}$ & $\begin{array}{r}14.80 \\
1.51\end{array}$ & $\begin{array}{r}17.50 \\
2.50\end{array}$ & $\begin{array}{r}14 \cdot 40 \\
4.04\end{array}$ & $\begin{array}{r}14 \cdot 10 \\
0.99\end{array}$ & $\begin{array}{r}14.40 \\
0.49\end{array}$ & $\begin{array}{r}15 \cdot 30 \\
1 \cdot 12\end{array}$ & $\begin{array}{r}15 \cdot 90 \\
2 \cdot 10\end{array}$ & $\begin{array}{r}15.30 \\
1.79\end{array}$ \\
\hline 13 & $\begin{array}{r}16 \cdot 20 \\
2 \cdot 17\end{array}$ & $\begin{array}{r}14.90 \\
1.43\end{array}$ & $\begin{array}{r}15.40 \\
1.60\end{array}$ & $\begin{array}{r}14 \cdot 10 \\
1 \cdot 43\end{array}$ & $\begin{array}{r}14.90 \\
0.77\end{array}$ & $\begin{array}{r}15 \cdot 00 \\
1.11\end{array}$ & $\begin{array}{r}13.80 \\
0.62\end{array}$ & $\begin{array}{r}16.50 \\
1.83\end{array}$ & $\begin{array}{r}14.50 \\
1.17\end{array}$ \\
\hline 14 & $\begin{array}{r}15 \cdot 70 \\
1 \cdot 48\end{array}$ & $\begin{array}{r}15.90 \\
1.21\end{array}$ & $\begin{array}{r}16 \cdot 00 \\
2 \cdot 00\end{array}$ & $\begin{array}{r}15.30 \\
2.68\end{array}$ & $\begin{array}{r}15 \cdot 00 \\
1.11\end{array}$ & $\begin{array}{r}14.90 \\
0.77\end{array}$ & $\begin{array}{r}15.30 \\
1.12\end{array}$ & $\begin{array}{r}15 \cdot 10 \\
0.54\end{array}$ & $\begin{array}{r}14 \cdot 10 \\
0.99\end{array}$ \\
\hline 15 & $\begin{array}{r}18 \cdot 15 \\
2 \cdot 09\end{array}$ & $\begin{array}{r}15.80 \\
1.29\end{array}$ & $\begin{array}{r}15 \cdot 80 \\
2 \cdot 40\end{array}$ & $\begin{array}{r}16 \cdot 10 \\
1.43\end{array}$ & $\begin{array}{r}14.60 \\
1.60\end{array}$ & $\begin{array}{r}14.20 \\
0.84\end{array}$ & $\begin{array}{r}15.20 \\
1.07\end{array}$ & $\begin{array}{r}14 \cdot 60 \\
1 \cdot 38\end{array}$ & $\begin{array}{r}15.40 \\
2.04\end{array}$ \\
\hline 16 & $\begin{array}{r}15.50 \\
1.74\end{array}$ & $\begin{array}{r}15.44 \\
1.03\end{array}$ & $\begin{array}{r}15.90 \\
1.66\end{array}$ & $\begin{array}{r}16.70 \\
2.01\end{array}$ & $\begin{array}{r}15 \cdot 30 \\
1 \cdot 12\end{array}$ & & $\begin{array}{r}16 \cdot 10 \\
0.99\end{array}$ & $\begin{array}{r}14 \cdot 20 \\
0.40\end{array}$ & $\begin{array}{r}15.40 \\
2 \cdot 27\end{array}$ \\
\hline 17 & & $\begin{array}{r}14.25 \\
1.07\end{array}$ & $\begin{array}{r}15 \cdot 40 \\
2 \cdot 49\end{array}$ & $\begin{array}{r}16.70 \\
0.90\end{array}$ & $\begin{array}{r}15 \cdot 10 \\
0.99\end{array}$ & & $\begin{array}{r}14.40 \\
0.71\end{array}$ & $\begin{array}{r}15 \cdot 70 \\
2 \cdot 01\end{array}$ & $\begin{array}{r}14.30 \\
0.46\end{array}$ \\
\hline 18 & & & $\begin{array}{r}17.90 \\
1.43\end{array}$ & $\begin{array}{r}15 \cdot 00 \\
3 \cdot 11\end{array}$ & $\begin{array}{r}15.50 \\
0.94\end{array}$ & & $\begin{array}{r}14.50 \\
0.94\end{array}$ & $\begin{array}{r}15 \cdot 60 \\
0.71\end{array}$ & $\begin{array}{r}15.20 \\
0.62\end{array}$ \\
\hline 19 & & & $\begin{array}{r}16.50 \\
0.94\end{array}$ & & $\begin{array}{r}14.80 \\
1.29\end{array}$ & & $\begin{array}{r}14.20 \\
3.73\end{array}$ & & $\begin{array}{r}15 \cdot 40 \\
2 \cdot 71\end{array}$ \\
\hline 20 & & & $\begin{array}{r}17 \cdot 20 \\
2 \cdot 40\end{array}$ & & $\begin{array}{r}15.80 \\
0.84\end{array}$ & & $\begin{array}{r}12 \cdot 60 \\
2 \cdot 27\end{array}$ & & $\begin{array}{r}15.90 \\
1.43\end{array}$ \\
\hline 21 & & & $\begin{array}{r}15.20 \\
0.62\end{array}$ & & $\begin{array}{r}14 \cdot 10 \\
1 \cdot 21\end{array}$ & & $\begin{array}{r}16.20 \\
0.84\end{array}$ & & \\
\hline 22 & & & & & $\begin{array}{r}14.90 \\
0.54\end{array}$ & & & & \\
\hline 23 & & & & & $\begin{array}{r}15 \cdot 20 \\
0.62\end{array}$ & & & & \\
\hline 24 & & & & & $\begin{array}{r}15 \cdot 60 \\
2 \cdot 04\end{array}$ & & & & \\
\hline $\begin{array}{r}\operatorname{can} \bar{x} a \\
v x\end{array}$ & $\begin{array}{r}16.94 \\
1.73\end{array}$ & $\begin{array}{r}15.77 \\
1.34\end{array}$ & $\begin{array}{r}16.47 \\
1.47\end{array}$ & $\begin{array}{r}14.89 \\
1.50\end{array}$ & $\begin{array}{r}15 \cdot 19 \\
1 \cdot 19\end{array}$ & $\begin{array}{r}15.25 \\
1.29\end{array}$ & $\begin{array}{r}14.77 \\
1.31\end{array}$ & $\begin{array}{r}15 \cdot 16 \\
1.01\end{array}$ & $\begin{array}{r}14.94 \\
1.41\end{array}$ \\
\hline
\end{tabular}


NR population mean is significantly different from AP, FA and LP. These are the only significant differences.

Examination of the numbered bodies showed that these three populations (OM, GG and NR) were readily distinguishable from the others on a number of morphological characters. Thus the average femur length, length of pronotum and convexity of hind pronotal margin were consistently different $(5.28 \pm 0.17 \mathrm{~mm}$. $v 7.79 \pm 0.36 \mathrm{~mm}$.; $1.93 \pm 0.08 \mathrm{~mm}$. $v 3.05 \pm 0.18 \mathrm{~mm}$; less rounded $v$ more convex respectively). Some of the bodies collected by

TABLE 3

Analysis of variance on the chiasma frequency data in table 2

\begin{tabular}{|c|c|c|c|c|}
\hline Item & d.f. & MS & VR & $P$ \\
\hline $\begin{array}{l}\text { (a) Mean cell chiasma f } \\
\text { Between populations } \\
\text { Within populations }\end{array}$ & $\begin{array}{r}8 \\
161\end{array}$ & $\begin{array}{r}10.4549 \\
0.9409\end{array}$ & $11 \cdot 1115$ & $\begin{array}{c}<0.001 * * * * \\
-\end{array}$ \\
\hline $\begin{array}{l}\text { (b) Between-cell variance } \\
\text { Between populations } \\
\text { Within populations }\end{array}$ & $\begin{array}{r}8 \\
161\end{array}$ & $\begin{array}{l}0.7183 \\
0.5288\end{array}$ & 1.3583 & $>0.20$ \\
\hline
\end{tabular}

Mesa at OM, now in the Australian National Insect Collection in Canberra were also small, thus indicating that the size difference of the OM population at least, is constant over time. Although Bigelow (1967) has stated that the taxonomic significance of variation in Phaulacridium marginale requires further study, he does not favour recognition of more than one species at this time. Should further collections reveal consistent differences in size and habitat preference, then the taxonomic status of $P$ h. marginale as a single species must be called into question, especially if any differences are confirmed by laboratory breeding experiments.

Previous studies on B chromosomes and extra segments have revealed that both types of supernumerary heterochromatin influence not only the total number of chiasmata formed but also their distribution (John and Hewitt, 1965a, b, 1966; Cameron and Rees, 1967; Jones and Rees, 1967; Hewitt and John, 1968; Westerman, 1969, 1970; Zečević and Paunović, 1969; Shaw, 1970; Simchen et al., 1970). Evidence on the mode of action of B's and segments is equivocal, with some workers claiming threshold effects (John and Hewitt, 1966, 1969) and others claiming dosage effects (Westerman, 1969; Zečević and Paunović, 1969; Shaw, 1971). Owing to the small number of individuals sampled from the Omarama population and to the large number of karyotypic classes consequent upon the extensive polymorphisms, no meaningful conclusions can be drawn for the effect of the extra heterochromatin on chiasma formation. Martin in 91 individuals sampled from Wellington claims no influence of the telocentric B chromosome on chiasma number.

Whether or not B chromosomes and extra segments influence chiasma frequency in the same manner is unknown at present and comparisons are difficult particularly because the two types of polymorphism are usually studied in different species. Large samples taken from populations such as OM where most individuals carry both B's and segments, should allow an analysis of their behaviour in the same genetic background and reveal any synergistic effects. Such a collection is in hand. 
Acknowledgments.-We would like to thank Dr A. Mesa for making material available to one of us (P. G. F.) for analysis. We would also like to acknowledge the financial assistance of the Department of Genetics and Human Variation, La Trobe University.

\section{REFERENCES}

Battaglia, E. 1964. Cytogenetics of B chromosomes. Caryologia, 17, 245-299.

BIGELow, R. s. 1967. The Grasshoppers (Acrididae) of New Zealand. University of Canterbury Publications: No. 9. Christchurch, New Zealand.

CAMERON, r. M., AND REEs, H. 1967. The influence of B chromosomes on meiosis in Lolium. Heredity, 22, 1967.

HEWTrT, G. M., AND JOHN, B. 1968. Parallel polymorphism for supernumerary segments in Chorthippus parallelus (Zetterstedt). I. British populations. Chromosoma (Berl.) 25, 319342.

HEWTT, G. M., AND JoHN, B. 1969. The B-chromosome system of Myrmelestettix maculatus (Thunb.). IV. The dynamics. Evolution, 24, 169-180.

HEWTrT, G. M., AND JOHN, B. 1971. The cytogenetic systems of grasshoppers and locusts. I. Chortoicetes terminifera. Chromosoma (Berl.), 34, 302-323.

HEWTrT, p. M., AND SGHROETER, G. 1968. Population cytology of oedaleonotus. I. The karyotypic faces of Oedaleonotus enigma (Scudder). Chromosoma (Berl.), 25, 121-140.

JACKson, W. D., AND CHEUNG, D. s. M. 1967. Distortional meiotic segregation of a supernumerary chromosome producing differential frequencies in the sexes in the shorthorned grasshopper Phaulacridium vittatum. Chromosoma (Berl.), 23, 24-37.

JoHn, B., AND HEWITT, G. м. 1965a. The B-chromosome system of Myrmeleotettix maculatus (Thunb.). I. The mechanics. Chromosoma (Berl.), 16, 548-578.

JoHN, B., AND HEWITT, G. м. 1965b. The B-chromosome system of Myrmeleotettix maculatus (Thunb.). II. The statics. Chromosoma (Berl.), 17, 121-138.

JOHN, B., AND HEWITT, G. M. 1966. A polymorphism for heterochromatic supernumerary segments in Chorthippus parallelus. Chromosoma (Berl.), 18, 254-271.

JoHN, B., AND HEWITT, G. M. 1969. Parallel polymorphism for supernumerary segments in Chorthippus parallelus (Zetterstedt). III. The ashurst population. Chromosoma (Berl.) 28, 73-84.

JONES, R. N., AND REES, H. 1967. Genotypic control of chromosome behaviour in rye. XI. The influence of B-chromosomes on meiosis. Heredity, 22, 333-347.

LIMA-DE-PARIA, A. 1963. The evolution of the structural pattern in a rye B-chromosome. Evolution, 17, 289-295.

MARTIN, J. M. 1970a. The use of grasshopper chromosomes to demonstrate meiosis. Tuatara, $18,1-12$.

MARTIN, J. M. 1970b. Thecytogenetics of some New Zealand grasshoppers (Acrididae). M.Sc. Thesis, Victoria University of Wellington.

MÜNTZING, A. 1954. Cytogenetics of accessory chromosomes (B-chromosomes). Caryologia (Firenze), 6, suppl., 282-301.

NUR, U. 1961. Meiotic behavi6ur of an unequal bivalent in the grasshopper Calliptamus palaestinensis Bdhr. Chromosoma (Berl.), 12, 272-279.

NUR, U. 1969. Mitotic instability leading to an accumulation of B-chromosomes in grasshoppers. Chromosoma (Berl.), 27, 1-19.

sHAW, D. D. 1970. The supernumerary segment system of Stethophyma. I. Structural basis. Chromosoma (Berl.), 30, 326-343.

sHAw, D. D. 1971. The supernumerary segment system of Stethophyma. II. Heterochromatin polymorphism and chiasma variation. Chromosoma (Berl.), 34, 19-39.

SIMCHEN, G., ZARCHI, Y., AND HILLEL, J. 1971. Supernumerary chromosomes in the second outbreeding species of the wheat group. Chromosoma (Berl.), 33, 63-69.

steel, G. D., AND torrey, J. H. 1960. Principles and Procedures of Statistics. McGraw-Hill, New York.

WEsterman, M. 1969. Parallel polymorphism for supernumerary segments in Chorthippus parallelus (Zetterstedt). II. French populations. Chromosoma (Berl.), 26, 7-21.

westzrman, M. 1970. Parallel polymorphism for supernumerary segments in Chorthippus parallelus. V. A new polymorphism in Europe. Heredity, 25, 662-667.

whrte, M. J. D. 1954. Animal Cytology and Evolution, 2nd edition. Cambridge University Press, Cambridge.

ZEČEvić, L., AND PAUNović, D. 1969. The effect of B-chromosomes on chiasma frequency in wild populations of rye. Chromosoma (Berl.), 27, 198-200. 
